\title{
ВПЛИВ УЛЬТРАДИСПЕРСНИХ НАНОАЛМАЗІВ ДЕТОНАЦИЙНОГО СИНТЕЗУ НА ПРОДУКТИВНІСТЬ ВІВЦЕМАТОК, IHТЕНСИВНІСТЬ РОСТУ ЯГНЯТ ТА ОКРЕМІ БІОХІМІЧНІ ПОКАЗНИКИ СИРОВАТКИ КРОВІ
}

\author{
Корх Ігор Володимирович \\ кандидат сільськогосподарських наук, старший науковий співробітник \\ Інститут тваринництва НААН \\ ORCID: 0000-0002-8077-895X \\ E-mail: dr.fox2011@ukr.net \\ Помітун Іван Андрійович \\ доктор сільськогосподарських наук, профессор \\ Інститут тваринництва НААН \\ ORCID: 0000-0002-7743-3600 \\ E-mail: pomitun@ukr.net \\ Косова Надія Олександрівна \\ кандидат сільськогосподарських наук, старший науковий співробітник \\ Інститут тваринництва НААН \\ ORCID: 0000-0001-7353-1994 \\ E-mail: nadokos5@gmail.com
}

Бойко Наталія Володимирівна кандидат сільськогосподарських наук, старший науковий співробітник Інститут тваринництва НААН ORCID: 0000-0001-6742-8456 E-mail: nbojko775@gmail.com

Паньків Любов Петрівна кандидат сільськогосподарських наук, старший науковий співробітник Інститут тваринництва НАAН ORCID: 0000-0002-3295-2132 E-mail: itanimalnaan@gmail.com

Рязанов Павло Олександрович науковий співробітник Інститут тваринництва НАAН ORCID: 0000-0001-7064-7182 E-mail: ryazanovpavel68@gmail.com

Іващенко Володимир Миколайович директор ТОВ НВП „,Sinta” Інститут тваринництва НАAН E-mail: Ivashchenko8888@gmail.com

Бородін Володимир Григорович технічний директор ТОВ НВП „,Sinta” Інститут тваринництва НАAН E-mail: vl.borodin@ukr.net

у статmі представлено результати досліджень з визначення ефекттиних способів уведення та перспективності використання 0,005 \% і 0,02 \% ультрадисперсної суспензії наноалмазів як можливого активатора фізіолого-біохімічного статусу та поліпшення продуктивних якостей овець харківського внутрішньопородного типу породи прекос. Реалізація поставлених завдань роботи передбачала використання комплексу загальноприйнятих аналітичних, зоотехнічних, біохімічних, біометричних методів. У рамках проведених пошукових експериментів встановлено покращення хімічного складу молока вівцематок, яке супроводжувалось збільшенням вмісту масової частки жиру та значним зниженням вмісту соматичних клітин. Зокрема, за вмістом масової частки жиру вівцематки дослідної групи мали незначну перевагу на 5,7 \% над представницями контрольної групи, тоді як за вмістом білку, навпаки, поступались їм - на 13,3 \%. Вміст масових часток сухої речовини, сухого знежиреного залишку та лактози перебував майже на одному рівні. Щодо молодняку: суспензія наноалмазів забезпечила незначне підвищення інтенсивності росту, 
рівня збереженості та поліпшення загального фізіологічного стану. В цілому, за період від 20 діб до 3-місячного віку, суспензії наноалмазів сприяла підвищенню середньодобових приростів у дослідних ягнят, які були на 10,6-11,3 \% вищими порівняно з контрольними, що й вплинуло на збільшення їх живої маси при відлученні на 6,7 і 6,9% проти контролю. Крім того, незначне підвищення в сироватиі крові молодняку дослідних груп у кінці досліду загального білка на 2,7 і 8,6 \%, альбумінів - на 2,2 і 3,1 \%, гамма-глобулінів - на 5,6 і 1,8 \%, коефріцієнта А/Г - на 9,5 і 13,5 \% та глюкози - на 1,6 \% в обох випадках порівняння свідчить про підвищення в їх організмі кровотворних функцій та певне посилення обмінних процесів, що підтверджується вищою живою масою. Однак ці відмінності були на рівні тенденції. Тоді як введення суспензії наноалмазів різними способами (перорально і підшкірно) не мало істотної різниці. Для подальшого виявлення механізму впливу суспензії наноалмазів на організм овещь варто провести тривалішу перевірку його використання з залученням до груп більшої чисельності тварин та розширення низки фрізіологічних досліджень.

Ключові слова: суспензія наноалмазів, сироватка крові, жива маса, хімічний склад молока

DOI: https://doi.org/10.32845/bsnau.Ivst.2019.1-2.9

Постановка проблеми в загальному вигляді. На сьогодні як в Україні, так і за кордоном досить гостро стоїть проблема погіршення екологічної ситуації, що справляє на організм тварини безпосередній вплив при фатальній дії несприятливих чинників довкілля. На тлі постійних викидів в атмосферу токсичних речовин техногенного походження широкого розповсюдження набувають методи оцінки, реалізація яких ґрунтується на сорбційних властивостях окремих речовин [3]. Тобто вони забезпечують виведення з організму продуктів різного виду забруднення та охорону довкілля.

Перспективну роль у вирішенні цієї проблеми відіграють розробки в області нанотехнологій, які передбачають виробництво і застосування, як альтернативи органічних форм мікроелементів, добавок у вигляді ультрадисперсних часток металів [17]. До їх переваг слід віднести екологічну безпечність, економічну доцільність та ефрективність.

Серед широкого спектру ультрадисперсних металів на особливу увагу заслуговують наноалмази як однин із складних і цікавих об'єктів для дослідження. Власне термін ультрадисперсні алмази існує досить давно, але з недавнього часу застосовують термін наноалмази.

Крупним природним алмазам властиві унікальні фрізичні та хімічні властивості. При зменшенні їх розмірів до декількох нанометрів вони не лише зберігають характерні властивості макрокристалам, але й набувають істотно нових. Детонаційний синтез не єдиний спосіб створення алмазів незначних розмірів.

Аналіз останніх досліджень і публікацій. Останнім часом наноалмази застосовували як компоненти за синтезу каучуку, полімерів, виробництві антикорозійного покриття, бактерицидних тканин, матеріалів побутової хімії, для очищення води, тощо $[8,16,25]$. Проведені в останні роки дослідження доводять їх ефективність в медицині $[1,5,6$, $26,32]$, біотехнології [4], рослинництві [11, 12, 21], мілеорації [29], харчовій промисловості [20]. Ці напрями використання наноалмазів уже сформувалися доволі чітко.

Попри це впродовж останніх 15-20 років інтерес до біологічної дії наноалмазів детонаційного синтезу значно розширився. Цьому сприяли принципово нові області їх використання. Зокрема, наноалмази застосовують для сільськогосподарських тварин [2, 10, 14, 15, 18, 19, 22, 23, $24,28,31,33]$.

При цьому окремими дослідженнями встановлено, що наноформам мікроелементів властива невисока токсичність порівняно зі звичними джерелами металівмікроелементів [9, 13, 27, 30], а в окремих випадках і навпаки [7].

Але область використання наноалмазів на сільськогосподарських тваринах значно обмежується відсутністю

просування ефрективних нанотехнологій в галузь тваринництва. I як результат, багатьма фахівцями, не встановлено чіткого механізму впливу на організм тварин у зв'язку, перш за все, із неможливістю визначення рівня в органах і тканинах, що значно стримує поширення наноалмазів у тваринництво. А відсутність сучасної високотехнологічної приладової бази не може гарантувати їх оцінку за параметрами екологічної безпеки.

Використання наноалмазів детонаційного синтезу у вівчарстві $€$ новим пошуковим напрямом їх застосування, який потребує раціонального підходу. Оскільки незважаючи на усі позитивні боки використання наноалмазів у тваринництві відсутня одностайна думка фахівців, яким способом їх краще вводити до організму тварини: з кормом перорально, підшкірно чи внутрішньом'язово.

Згодовування наноалмазів перорально $€$ доступнішим і природнім способом, який не потребує жодних зусиль та спеціальних навиків для практика. За його реалізації зменшується ризик запальних процесів, абсцесів. Клінічним досвідом доведено, що застосування підшкірного введення препаратів $€$ аналогічним за властивостями до перорального. Тоді як внутрішньом'язовий спосіб введення $є$ найефективнішим в напрямі адресної доставки препарату. Однак він супроводжуються цілою низкою неприємних наслідків, потребує відповідного інструментарію та чіткого дотримання техніки маніпуляцій.

Власне зважаючи на це, вищезазначені положення складають підгрунтя до подальших поглиблених досліджень, визначають їх актуальність і вибір напряму роботи.

Метою досліджень $€$ визначення ефективних способів уведення та перспективності використання ультрадисперсної суспензії наноалмазів як можливого активатора фізіолого-біохімічного статусу і поліпшення продуктивних якостей овець харківського внутрішньопородного типу породи прекос.

Для досягнення мети були поставлені такі завдання:

- провести дослідження з визначення нешкідливості дослідного препарату на організм тварин;

- визначити відтворювальну здатність, молочну продуктивність вівцематок, якість їх молока, фізіологічний стан та збереженість одержаних ягнят;

- дослідити динаміку росту та рівень середньодобових приростів у баранців до 3-місячного віку;

- оцінити окремі біохімічні показники сироватки крові вівцематок та молодняку.

Матеріали та методи досліджень. Дослідження проведено в умовах вівцесрерми племінного господарства ДПДГ,Гонтарівка” Вовчанського р-ну Харківської області. Реалізація поставлених завдань роботи передбачала вико- 
ристання комплексу загальноприйнятих аналітичних, зоотехнічних, біохімічних, морфологічних та біометричних методів.

Першочерговий етап досліджень передбачав встановлення оптимальної концентрації введення суспензії наноалмазів на лабораторних мишах у процесі попередньої оцінки гострої токсичності. Для визначення гострої пероральної токсичності $\left(L D_{50}\right)$ суспензії УДА застосовували УДА виробництва ТОВ НВП „SINTA” (ТУ У 20.1-31234143003:2015 „АЛМАЗ УЛЬТРАДИСПЕРСНИЙ”). Для проведення дослідів використовували білих мишей. Перед введенням препарату їх не годували 4 години і такий же час витримували після введення препарату. Суспензію препарату вводили в два прийоми за допомогою шприцу з зондом, безпосередньо в шлунок із розрахунку, щоб об'єм розчину не перевищував 0,5 $\mathrm{cm}^{3}$ за один прийом на фоні введення по $0,5 \mathrm{~cm}^{3} 1 \%$ розчину етилового спирту, як шкідливої речовини. Проміжок часу між двома прийомами становив не більше 4 годин. Дослід складався з підготовчого періоду, тривалістю 7 діб, і облікового - 14 діб, протягом яких проводили постійне спостереження за лабораторними тваринами. У підготовчий період усі піддослідні тварини знаходились в умовах карантину і споживали однакові за видом корми. Дозу діючої речовини обчислювали у мг на 1 кг живої маси. Для досліду сформували п'ять груп, які були аналогами за віком і статтю, але різнилися рівнем введення етилового спирту. Піддослідні миші перед початком досліду були клінічно здорові, температурний режим при проведенні досліджень варіював від $18^{\circ} \mathrm{C}$ до $20^{\circ} \mathrm{C}$, утримання - у клітках на дерев'яній тирсі, годівля - дворазова.

На початку та наприкінці токсикологічних досліджень мишей зважували. Забивали методом декапітації, після якої здійснювали повний розтин черевної порожнини, внутрішні органи - зажували та оцінювали морфологічний стан.

Ультрадисперсні наноалмази (виробник ПОВ НВП „SINTA”, м. Харків), використані у досліді, одержані механохімічним способом за технологією детонаційного синтезу. Тобто вони являють собою продукт вибухового розкладу суміші тротил-гексогену $50 / 50$ із негативним кисневим балансом і наступною хімічною очисткою продуктів детонації (алмазовмісної шихти) сильними окисниками, зокрема, нітратною кислотою.

Вибух проводився у спеціальній камері з нержавіючої сталі у безкисневій атмосфері. На властивості наноалмазів впливають розміри алмазних кристалів та наявність на їх поверхні активних функціональних груп. Середній розмір алмазних кристалів дорівнює 3-10 нм (0,003-0,006 мкм), частинки ультрадисперсного алмаза мають округлу форму без вираженої кристалічної огранки.

Площа питомої поверхні порошку наноалмазів становить 300-450 м²/г, густина (пікнометрична) - 3,05-3,35

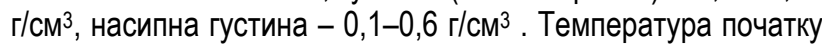
окислення ультрадисперсних алмазів на повітрі знаходиться в межах $450-500{ }^{\circ} \mathrm{C}$, температура графітизації - $1100{ }^{\circ} \mathrm{C}$. Ультрадисперсний алмаз стійкий до дії рідкофазних окиснювачів та кислот, утворює стабільні колоїдні дисперсії (суспензії) як у деіонізованій і дистильованій воді, так і полярних органічних розчинниках.

3 метою організації першого досліду сформували дві групи глибокосуягних вівцематок, аналогів за датою осіменіння, по 50 голів у кожній. Відмінності між групами полягали у тому, що вівцематкам II (дослідної) групи за 10 діб до запланованого ягніння три доби поспіль, згідно рекомендацій підприємства виробника, підшкірно вводили 0,005 \% ультрадисперсної суспензії наноалмазів, розчинену на глюкозі у дозі 5 мл/голову. Першій (контрольній) групі за цією ж схемою вводили аналогічну кількість розчину глюкози.

Основний раціон обох груп вівцематок був аналогічним за складом кормів: сіно люцернове, силос кукурудзяний, дерть вівса і 100 г кормової добавки захищеного байпас-протеїну.

3 метою визначення впливу ультрадисперсної суспензії наноалмазів на інтенсивність росту та зміни біохімічних показників крові ягнят залежно від способів ії введення до організму (пероральному споживанні та підшкірному введенні) провели другий дослід. Новонароджений молодняк розподілили на три групианалоги, по 20 голів у кожній (1 контрольна та 2 групи дослідні). Із одержаного приплоду від вівцематок контрольної групи попереднього досліду ссрормували першу групу, якій підшкірно вводили розчин глюкози в дозі 5 мл 3 розрахунку на одну голову. Молодняк, одержаний від дослідної групи вівцематок розподілили на дві групи другу і третю.

При цьому, молодняку II (дослідної) групи підшкірно вводили 0,02 \% ультрадисперсної суспензії наноалмазів розчиненої на $5 \%$ розчині глюкозі у дозі 5 мл з розрахунку на одну голову в перші 3 доби після формування групи, в подальшому - 1 мл один раз у 3 доби. На місці введення препарату вовну вистригали, а безпосереднє місце проколу шкіри голкою помічали маркером. Молодняку III (дослідної) групи 0,01 \% препарат, розчинений на дистильованій воді, вводили перорально у дозі 10 мл з розрахунку на одну голову перші 5 діб, в подальшому - один раз через одну добу. Тривалість введення препаратів - протягом першого місяця після народження. Для досліду використовували свіжовиготовлений розчин, який був розлитий в чисту скляну тару, герметично закупорену гумовою пробкою з алюмінієвої обкаткою і стерилізований в автоклаві, перед застосуванням розчин збовтували і підігрівали до температури тіла. У ході проведення обох дослідів вели спостереження за кормовою збудливістю піддослідних тварин та загальним станом.

Відтворювальну здатність вівцематок оцінювали за загальноприйнятою методикою шляхом визначення запліднюваності, плодючості, підрахунку кількості живих і мертвонароджених ягнят, рівнем їх збереження в розрахунку на 100 маток.

Молочність маток визначали непрямим методом, шляхом множення одержаного ягнятами приросту живої маси за перші 20 діб лактації на коефіцієнт 5. Для цього відібрали по 5 вівцематок. Одночасно відібрали зразки молока для хімічного аналізу.

Визначення змін росту піддослідного молодняку здійснювали за результатами індивідуального їх зважування. За даними живої маси розраховували середньодобові та відносні її прирости.

Дослідження біохімічних показників сироватки крові овець виконували в умовах Випробувального центру IT НААН, акредитованого Національним агентством 3 акредитації України відповідно до вимог ДСТУ ISO/IEC 17025 : 2006. Кров для аналізів відбирали вранці до годівлі 
від трьох-чотирьох тварин із кожної групи натщесерце. У сироватці крові визначали: рівень загального білка методом Кингеля-Вейксельбаума за біоретовою реакцією; вміст альбумінів, альфа-, бета-, і гамма-глобулінів турбідиметричним методом, рівень глюкози глюкозооксидазним методом, холестерина ферментативним методом Триндера, креатиніна - методом Яфре-Поппера, рівень активності ферментів амінотрансфераз - динітрофенілгідразиновим методом Райтмана-Френкеля, лужної фосфатази - за реакцією 3 фенілфоссратом.

Досліди проводили згідно з вимогами Європейської конвенції із захисту тварин, що використовуються для експериментальних і наукових цілей (м. Страсбург, 1985) та національних ,ЗЗагальних етичних принципів експериментів на тваринах" (Україна, 2001). Цифровий матеріал експериментальних досліджень опрацьовували біометричними методами за використання персонального комп'ютера та пакету прикладних програм MS Excel 2003 на основі розрахунку середньої арифметичної (М), відхилення показників від середньої арифметичної похибки $(\mathrm{m})$ та рівня вірогідності різниці між порівнюваними групами (р). Варіаційні ряди порівнювали за t-критерієм Стьюдента, різницю між групами вважали вірогідною при $p<0,05$, тобто в тих випадках, коли вірогідність результатів рівна $95 \%$ і більше.

Результати досліджень. На підставі лабораторних досліджень 3 визначення гострої токсичності препарату варто зазначити, що нами не встановлено суттєвої різниці за рівнем змін живої маси піддослідних мишей жодної з груп впродовж періоду спостережень: у цілому вона коливалася від 20,8 г до 21,1 г на їх початку та від 21,6 г до 22,0 г наприкінці.

У перші хвилини після введення розчину етилового спирту, незалежно від його рівня, піддослідні тварини рухалися по колу, серед них спостерігали легке пригнічення та загальмованість у рухах, вони часто дихали. Через 20-30 хвилин їх стан нормалізувався, але з'явилась спрага, а через 1 годину вони здебільшого лежали. Через 2,5-3 години їх стан повністю відновлювався. Після повторного введення розчину етилового спирту поведінка тварин була схожою на ту, яку спостерігали після першого введення препарату.

Попри це вже на другу добу в мишей відмічали поновлення апетиту, але деяке збільшення споживання ними води. Рухова активність тварин, в основному, знаходилась у межах добових коливань і мало відрізнялася у розрізі груп. На кінець досліду всі тварини, незалежно від групи, залишилися живими, клінічних та патологічних змін в морфологічному стані внутрішніх органів не виявлено і тому досліджуваний препарат віднесли до нетоксичних, а досліджувані концентрації екстраполювали на овець 3 урахуванням їх живої маси. За абсолютною масою внутрішніх органів суттєвої різниці між групами також не встановлено.

у процесі опрацювання результатів візуальних спостережень за перебігом ягніння вівцематок з'ясовано, що воно проходило досить швидко і без ускладнень. У середньому на 100 маток у дослідних групах одержано 115 ( група -111; || група - 119) ягнят. Випадків занепокоєння серед них не зафіксовано. Послід відділявся вчасно: у вівцематок контрольної групи з коливаннями від 1 год 45 хв до 2 годин 18 хв, у дослідної - від 1 години 23 хв до 1 години 57 хв. Впливу застосування препарату на материнську поведінку вівцематок не виявлено.

За біохімічними показниками сироватки крові перевагу дослідної групи вівцематок над контрольною виявити також не вдалося, усі вони знаходилися в межах фізіологічної норми. Попри це у вівцематок дослідної групи в кінці досліду відмічалося незначне підвищення суми глобулінів, у тому числі $\beta$-глобулінів та рівня амінотрансфрераз, втім у представниць контрольної групи виявлено незначне зростання альбумінів та $\mathrm{y}$-глобулінів (табл. 1).

Таблиия 1

Біохімічні показники сироватки крові вівцематок, $\mathrm{M \pm m}$, ( $\mathrm{n}=$ по 4 голови у кожній групі)

\begin{tabular}{|l|c|c|}
\hline \multicolumn{1}{|c|}{ Показник } & $\begin{array}{c}\text { II дослідна група } \\
\text { (підшкірне введення розчину глюкози) }\end{array}$ & $\begin{array}{c}\text { І } \\
\text { (підшкірне введення препарату) }\end{array}$ \\
\hline \multicolumn{1}{|c|}{ Кінець досліду } & $66,25 \pm 0,85$ \\
\hline Загальний білок, г/л & $66,25 \pm 0,85$ & $42,00 \pm 1,07$ \\
\hline Альбуміни, \% & $42,68 \pm 0,65$ & $58,00 \pm 1,07$ \\
\hline Сума глобулінів, \% & $57,32 \pm 0,65$ & $0,73 \pm 0,03$ \\
\hline Коефіцієнт А/Г & $0,75 \pm 0,03$ & $19,85 \pm 1,13$ \\
\hline Вміст: а-глобулінів, \% & $19,90 \pm 0,74$ & $13,83 \pm 1,04$ \\
\hline В-глобулінів, \% & $11,68 \pm 0,35$ & $24,33 \pm 0,75$ \\
\hline ү-глобулінів, \% & $25,75 \pm 1,12$ & $4,63 \pm 0,08$ \\
\hline Глюкоза, ммоль/л & $4,63 \pm 0,26$ & $100,50 \pm 2,66$ \\
\hline Креатинін, ммоль/л & $100,75 \pm 2,84$ & $3,33 \pm 0,06$ \\
\hline Холестирін, ммоль/л & $3,33 \pm 0,06$ & $39,75 \pm 1,55$ \\
\hline АсАТ, од/л & $38,75 \pm 1,03$ & $20,50 \pm 2,22$ \\
\hline АлАТ, од/л & $20,00 \pm 0,00$ & $70,75 \pm 4,31$ \\
\hline Лужна фоссфатаза, од/л & $70,75 \pm 4,31$ & \\
\hline
\end{tabular}

Результати хімічного аналізу молока (табл. 2) свідчать про те, що за вмістом масової частки жиру вівцематки дослідної групи мали незначну перевагу на 5,7 \% над представницями контрольної групи, тоді як за вмістом масової частки білку, навпаки, поступались їм - на 13,3%. Вміст масових часток сухої речовини, протеїну та лактози перебував майже на одному рівні, але 3 незначною перевагою вівцематок контрольної групи. 
Таблиця 2

Хімічний склад молока вівцематок, $M \pm m,(n=$ по 5 голів у кожній групі)

\begin{tabular}{|l|c|c|}
\hline \multicolumn{1}{|c|}{ Показник } & $\begin{array}{c}\text { I контрольна група } \\
\text { (підшкірне введення розчину глюкози) }\end{array}$ & $\begin{array}{c}\text { II дослідна група } \\
\text { (підшкірне введення препарату) }\end{array}$ \\
\hline Масова частка жиру, \% & $5,28 \pm 0,21$ & $5,58 \pm 0,43$ \\
\hline Масова частка білка, \% & $4,45 \pm 0,09$ & $3,86 \pm 0,31$ \\
\hline Масова частка лактози, \% & $5,74 \pm 0,04$ & $5,57 \pm 0,07$ \\
\hline Масова частка сухої речовини, \% & $16,40 \pm 0,17$ & $15,96 \pm 0,36$ \\
\hline Масова частка протеїну, \% & $4,68 \pm 0,08$ & $4,11 \pm 0,29$ \\
\hline Вміст соматичних клітин (тис/см $\left.{ }^{3}\right)$ & $1912,8 \pm 767$ & $75,6 \pm 18,21$ \\
\hline
\end{tabular}

Використання суспензії наноалмазів забезпечило значне зниження вмісту соматичних клітин в молоці вівцематок дослідної групи (майже в 25 разів), при статистично вірогідній різниці щодо контрольної групи $(p<0,05)$. Разом із тим, молочність вівцематок дослідної групи в перші 20 діб лактопоезу становила 33,7 кг, що на 9,1 $\%$ більше порівняно з аналогічним показником контрольної групи.

При аналізі показників росту ягнят (табл. 3) від народження до 3-місячного віку встановлено, що жива маса при народженні як I (контрольної), так і II (дослідної) груп була майже на одному рівні й становила відповідно 4,12 кг та 4,14 кг, за незначної переваги над ними представників III (дослідної) групи на 3,6 \%.

Таблиия 3

Динаміка росту піддослідних ягнят, $M \pm m$, (n = по 20 голів у кожній групі)

\begin{tabular}{|l|c|c|c|}
\hline \multicolumn{1}{|c|}{ Показник } & $\begin{array}{c}\text { I контрольна група } \\
\text { (підшкірне введення розчину глюкози) }\end{array}$ & $\begin{array}{c}\text { II дослідна група } \\
\text { (підшкірне введення препарату) }\end{array}$ & $\begin{array}{c}\text { III дослідна група } \\
\text { (пероральне введення препарату) }\end{array}$ \\
\hline \multicolumn{3}{|c|}{ Жива маса, кг } \\
\hline при народженні & $4,12 \pm 0,25$ & $4,27 \pm 0,15$ & $4,14 \pm 0,25$ \\
\hline в 20 діб & $8,89 \pm 0,41$ & $9,45 \pm 0,36$ & $9,60 \pm 0,60$ \\
\hline у 3 місяці & $21,82 \pm 0,77$ & $23,56 \pm 0,81$ & $23,29 \pm 0,85$ \\
\hline \multicolumn{3}{|c|}{ Середньодобовий приріст, г } \\
\hline за ембріональний період & $27,75 \pm 1,62$ & $26,68 \pm 1,02$ & $27,56 \pm 1,62$ \\
\hline від народження до 20 діб & $238,5 \pm 12,2$ & $259,19 \pm 13,14$ & $273,2 \pm 20,50$ \\
\hline від 20 діб до 3-х місяців & $194,3 \pm 8,6$ & $216,21 \pm 8,83$ & $214,8 \pm 6,80$ \\
\hline
\end{tabular}

За майже однакового складу молока вища молочність вівцематок сприяла більшій інтенсифікації росту дослідних ягнят. Зокрема, у віці 20 діб молодняк обох дослідних груп за величиною живої маси майже зрівнявся (9,45-9,60 кг) і перевищував ровесників контрольної групи відповідно - на 6,3 і 8,0 \%. Пероральне введення препарату у цей же період супроводжувалось збільшенням на 14,5\% інтенсивності росту молодняку щодо особин контрольної групи та на 5,4 \% - порівняно представників II (дослідної) групи.

Між тим поступаючись їм ягнята, яким вводили препарат підшкірно, також переважали ровесників контрольної групи на 8,7\%. Але статистично вірогідної різниці між ними не виявлено.

У цілому, за період від 20 діб до 3-місячного віку (період післядії), суспензії наноалмазів сприяла підвищенню середньодобових приростів у дослідних ягнят, які були на 10,6-11,3\% вищими порівняно 3 контрольними, що й вплинуло на збільшення їх живої маси при відлученні на 6,7 і 6,9 \% проти контролю.

Протягом застосування препаратів проводили візуальні спостереження за піддослідним молодняком. Виявлено, що рухова активність ягнят дослідних груп не різнилася від контрольної групи й знаходилась у межах добових коливань. Елементи поведінки були представлені іграми, активними пересуваннями по сакману та кормовими реакціями. Під час введення препаратів ягнята поводилися спокійно. Відразу після підшкірного введення препаратів негативних реакцій 3 їх боку не відмічали, а в місці проколу шкіри голкою не було ні почервоніння, ні припухлості.

Температура тіла, частота дихання і пульсу знаходились в межах фізіологічної норми для цього вікового періоду (відповідно $38,1-38,6$ C, 114,2-121,8 ударів за хвилину і 59,4-66,1 дихальних рухів за хвилину). На тлі застосування суспензії наноалмазів випадків загибелі серед піддослідних ягнят жодної з груп, погіршення апетиту, відмов від корму і води упродовж досліду не відмічалося, й тому використаний препарат у застосованих дозах можна віднести до нешкідливих.

Дослідженнями, проведеними 3 метою виявлення взаємозв'язку показників, що характеризують склад сироватки крові з продуктивністю ягнят встановлено, що основні біохімічні параметри протягом досліду перебували в межах фізіологічної норми, а використання суспензії наноалмазів не мало негативної дії на їх організм (табл. 4). 
Біохімічні показники сироватки крові піддослідного молодняку, $\mathrm{M \pm m}$, (n = по 3 голови у кожній групі)

\begin{tabular}{|l|c|c|c|}
\hline \multicolumn{2}{|c|}{ Показник } & $\begin{array}{c}\text { I контрольна група } \\
\text { (підшкірне введення розчину глюкози) }\end{array}$ & $\begin{array}{c}\text { I дослідна група } \\
\text { (підшкірне введення препарату) }\end{array}$ \\
\hline \multicolumn{3}{|c|}{ Кінець досліду (у місячному віці) } \\
(пероральне введення препарату)
\end{tabular}

Незначне підвищення в сироватці крові молодняку II і III дослідних груп у кінці досліду, порівняно з контролем, загального білка на 2,7 і 8,6 \%; альбумінів - на 2,2 і 3,1 \%; гамма-глобулінів - на 1,7 і 0,6\%; коефіцієнта А/Г - на 9,5 і $13,5 \%$ та глюкози - на 1,6 \% в обох випадках порівняння свідчить про підвищення в їх організмі кровотворних функцій та певне посилення обмінних процесів, що підтверджується вищою живою масою. Однак ці відмінності були на рівні тенденції. Міжгрупова різниця за іншими біохімічними показниками сироватки крові не є істотною.

Підвищення або зниження біохімічних показників сироватки крові в кінці досліду порівняно з початковим рівнем обумовлені віковими особливостями ягнят.

Висновки. 1. Установлено перспективність використання і позитивний вплив ультрадисперсної суспензії наноалмазів на хімічний склад молока вівцематок, який позначився на збільшенні вмісту масової частки жиру та значному зниженні вмісту соматичних клітин.

2. Суспензія наноалмазів забезпечує незначне підвищення інтенсивності росту, рівня збереженості ягнят та загального фізіологічного стану.

3. Введення ультрадисперсної суспензії наноалмазів різними способами (перорально і підшкірно) не мала істотної різниці.

На нашу думку для подальшого виявлення механізму впливу суспензії наноалмазів на організм овець варто провести тривалішу перевірку його використання з залученням до груп більшої чисельності тварин та розширення низки фізіологічних досліджень.

Автори публікації висловлюють глибоке визнання і вдячність дирекції та головним фахівцям ДП ДГ ,, Гонтарівка" за надану можливість у проведення досліджень і методичну допомогу в їх реалізації, зазначені на різних стадіях обговорення цінні зауваження та корисні побажання.

\section{Список використаної літератури:}

1. Акафьева Т.И., Звездин В. Н. Токсиколого-гигиеническая оценка потенциальной опасности для здоровья человека нанодисперсного раствора диоксида кремния. Вестник Пермского университета. Серия: Биология. 2012. № 2, С. 71-74.

2. Русакова Е.А., Лебедев С.В., Кван О.В., Рахматуллин Ш.Г., Сизова Е.А., Улиткина Д.В. Влияние наноразмерных частиц железа при интраперитонеальном введении на некоторые биохимические показатели крови животных. Известия Оренбургского государственного аграрного университета. 2012. Т. 33. № 1-1, С. 105-106.

3. Галченко Ю.П. Техногенные наночастицы как непериодический фрактор окружающей среды. Экологические системы и приборы. 2007. № 1, С. 18-22.

4. Головин Ю.И. Нанобиотехнологии. Наноинженерия. 2014. № 12 (42), С. 32-43.

5. Деев С.М., Лебеденко Е.Н. Адресные бифункциональные белки и гибридные наноструктуры в диагностике и терапии рака. Молекулярная биология. 2017. № 6, С. 907-926.

6. Богословская О.А., Сизова Е.А., Полякова В.С., Мирошников С.А., Лейпунский И.О., Ольховская И.П., Глущенко Н.Н. Изучение безопасности введения наночастиц меди с различными фризико-химическими характеристиками в организм животных. Вестник Оренбургского государственного университета. 2009. № 2 (108), С. 124-127.

7. Короткова А.М., Лебедев С.В., Сизова Е.А. Исследование механизмов развития прооксидантных эффектов наночастиц металлов переменной валентности в тесте Triticum Vulgare. Международный научно-исследовательский журнал. 2015. № 8-3 (39), С. 14-19.

8. Короткова А.М., Лебедев С.В., Сизова Е.А. Участие наночастиц никеля в регуляции образования френольных соединений в клетках Triticum Vulgare. Инновационные разработки по импортозамещению в агропродовольственном секторе: материалы междунар. науч.-практ. конф., посвящ. 85-летию Всероссийского НИИ мясного скотоводства / под ред. чл.-корр. РАН В.И. Левахина. Оренбург, 2015. С. 3-5.

9. Лебедев С.В., Гавриш И.А. Минеральный состав тканей Eisenia Fetida в присутствии в среде наночастиц оксида молибдена (VI). Микроэлементы в медицине. 2017. Т. 18. № 1, С. 38-42. 
10. Мирошников С.А., Сизова Е.А. Наноматериалы в животноводстве (обзор). Вестник мясного скотоводства. 2017. № 3 (99), С. 7-22.

11. Нотова С.В., Сизова Е.А., Казакова Т.В., Маршинская О.В. Морфобиохимические параметры крыс при введении наночастиц диоксида титана. Вестник мясного скотоводства. 2016. № 3 (95), С. 8-14.

12. Короткова А.М., Лебедев С.В., Каюмов Ф.Г., Сизова Е.А. Морфофизиологические изменения у пшеницы (Triticum VulgareL.) под влиянием наночастиц металлов (Fe, $\mathrm{Cu}, \mathrm{Ni})$ и их оксидов (Fe3O4, $\mathrm{CuO}, \mathrm{NiO})$. Сельскохозяйственная биология. 2017. Т. 52. № 1, С. 172-182.

13. Полякова В.С., Сизова Е.А., Мирошников С.А., Нотова С.В., Завалеева С.М. Морфофункциональная характеристика щитовидной железы при введении наночастиц меди Морфология. 2015. Т. 148. № 6, С. 54-58.

14. Муруев А.В., Жапов Ж..Н., Буянтуева Д.Т. Нанотехнологии в развитии животноводства. Вестник Бурятской государственной сельскохозяйственной академии им. В.Р. Филиппова. 2010. № 1, С. 7-16.

15. Яушева Е.В., Мирошников С.А., Косян Д.Б., Сизова Е.А. Наночастицы Ғе в сочетании с аминокислотами изменяют продуктивные и иммунологические показатели у цыплят-бройлеров. Сельскохозяйственная биология. 2016. Т. 51 . № 6. C, $912-920$

16. Зейналов О.А., Комбарова С.П., Багров Д.В., Петросян М.А., Толибова Г.Х., Феофанов А.В., Шайтан К.В. О влиянии наночастиц серебра на физиологию живых организмов. Обзоры по клинической фрармакологии и лекарственной терапии. 2016. T. 14. № 4, С. 42-51.

17. Сизова Е.А., Мирошников С.А., Лебедев С.В., Кудашева А.В., Рябов Н.И. О перспективности нанопрепаратов на основе сплавов микроэлементов-антагонистов (на примере Fе и Со). Сельскохозяйственная биология. 2016. Т. 51. № 4, С. 553-562.

18. Оробченко А.Л., Романько М.Е., Куцан А.Т. Экспериментально-теоретическое обоснование применения нанокомпозита металлов ( $\mathrm{Ag}, \mathrm{Cu}$. Fe и двуокись $\mathrm{Mn}$ ) для кур-несушек при условии хронического поступления с кормом (обобщение экспериментальных исследований). Ветеринария, зоотехния и биотехнология. 2014. № 12, С. 32-40.

19. Никитин А.Ю., Маркова И.В., Лебедев С.В., Сизова Е.А. Оценка физиолого-продуктивного потенциала цыплятбройлеров при частичной замене зерновой части рациона и введении ферментных препаратов в комбикорм. Вестник мясного скотоводства. 2017. № 3 (99), С. 171-177.

20. Павлов А. Н. Применение наночастиц в агропромышленном комплексе и пищевой промышленности. Инновационная наука как основа развития современного государства: сб. науч. ст. по итогам междунар. науч.-практ. конф. СПб., 2017. № 1, C. 254-257.

21. Райкова А.П. Использование нанопорошков металлов для предпосевной обработки семян сельскохозяйственных культур. Известия ТСХА. 2009. № 1, С. 59-65.

22. Сизова Е.А. Влияние включения в рацион наночастиц меди на уровень кадмия в организме цыплят-бройлеров. Вестник мясного скотоводства. 2017. № 1 (97), С. 13-20.

23. Сизова Е.А. Морфо-функциональные критерии оптимизации путей введения наноразмерных частиц меди в организм животных. Научное обозрение. 2012. № 1, С. 8-15.

24. Сизова Е.А., Мирошников И.С. Особенности обмена химических элементов в организме животных при внутримышечном введении наночастиц элементарного железа. Вестник мясного скотоводства. 2014. № 3 (86), С. 80-84.

25. Сизова Е.А., Романова А.П., Умрихина В.В. Использование фрлутуирующей асимметрии Alburnus Alburnus и Rana Ridibunda для оценки качества водной среды. Вестник Оренбургского государственного университета. 2017. № 8 (208), C. 76-79.

26. Сизова Е.А., Танцикужина А.А., Полякова В.С. Экспрессия маркера апоптоза в клетках печени при различных способах введения наночастиц меди. Вестник Оренбургского государственного университета. 2011. № 12(131), С. 436438 .

27. Слободсков А.А. Влияние внутримышечного введения наноразмерных частиц меди на биохимические показатели крови самок крыс при гестации. Современные проблемы науки и образования. 2014. № 1, С. 328.

28. Нестеров Д.В., Сипайлова О.Ю., Сизова Е.А., Шейда Е.В. Сравнительная оценка влияния различных способов введения наночастиц меди на обмен токсичных элементов в мышечной ткани цыплят-бройлеров. Актуальные проблемы транспортной медицины. 2014. № 3 (37), С. 146-150.

29. Чурилов Г. И. Нанокристалические металлы как экологически чистые микроудобрения. Сб. науч. тр. „Экологическое состояние природной среды и научно-практические аспекты современных мелиоративных технологий”. Вестник Оренбургского государственного университета. 2008. № 3, С. 84-86.

30. Нотова С.В., Тимашева А.Б., Лебедев С.В., Сизова Е.А., Мирошников С.В. Элементарный статус и биохимический состав крови лабораторных животных при внутримышечном введении аспаргината и наночастиц меди. Вестник Оренбургского государственного университета. 2013. № 12 (161), С. 159-163.

31. Miroshnikova E., Arinzhanov A., Kilyakova Y., Sizova E., Miroshnikov S. Antagonist metal alloy nanoparticles of iron and cobalt: impact on trace element metabolism in carp and chicken. Human and Veterinary Medicine. 2015. T. 7. № 4, C. $253-259$.

32. Pankhurst Q., Connolly J., Jones S. K. and Dobson J. Applications of magnetic nanoparticles in biomedicine. Journal of Physics D: Applied Physics. 2003. № 13, P. 87.

33. Sizova E., Yausheva E., Kosyan D., Miroshnikov S. Growth enhancement by intramuscular injection of elemental iron nano and microparticles. Modern Applied Science. 2015. T. 9. № 9, C. 17-26. 


\section{References:}

1. Akaf'eva, T.I., and Zvezdin. V.N., 2012. Toksikologo-gigienicheskaja ocenka potencial'noj opasnosti dlja zdorov'ja cheloveka nanodispersnogo rastvora dioksida kremnija [Toxicological and hygienic assessment of the potential danger to human health of a nanodispersed solution of silicon dioxide]. Vestnik Permskogo universiteta. Seriya: Biolohiya. issue, 2, pp. 71-74.

2. Rusakova. E.A., Lebedev. S.V., Kvan. O.V., Rahmatullin. Sh.G., Sizova. E.A. and Ulitkina. D.V., 2012. Vlijanie nanorazmernyh chastic zheleza pri intraperitoneal'nom vvedenii na nekotorye biohimicheskie pokazateli krovi zhivotnyh [Influence of nanosized iron particles during intraperitoneal administration on some biochemical parameters of animal blood]. Izvestija Orenburgskogo gosudarstvennogo agrarnogo universiteta. Vol. 33, issue 1-1, pp. 105-106.

3. Galchenko. Ju.P., 2007. Tehnogennye nanochasticy kak neperiodicheskij faktor okruzhajushhej sredy [Technogenic nanoparticles as a non-periodic environmental factor]. Jekologicheskie sistemy i pribory. issue 1, pp. 18-22.

4. Golovin Ju.I., 2014. Nanobiotehnologii [Nanobiotechnology]. Nanoinzhenerija. issue 12 (42), pp. 32-43.

5. Deev S.M. and Lebedenko E.N., 2017. Adresnye bifunkcional'nye belki i gibridnye nanostruktury v diagnostike i terapii raka [Targeted bifunctional proteins and hybrid nanostructures in the diagnosis and treatment of cancer]. Molekuljarnaja biologija. issue 6, pp. 907-926.

6. Bogoslovskaja O.A., Sizova E.A., Poljakova V.S., Miroshnikov S.A., Lejpunskij I.O., Ol'hovskaja I.P. and Glushhenko N.N., 2009. Izuchenie bezopasnosti vvedenija nanochastic medi s razlichnymi fiziko-himicheskimi harakteristikami $v$ organizm zhivotnyh [The study of the safety of the introduction of copper nanoparticles with various physico-chemical characteristics to the animal organism]. Vestnik Orenburgskogo gosudarstvennogo universiteta. issue 2 (108), pp. 124-127.

7. Korotkova A.M., Lebedev S.V. and Sizova E.A, 2015. Issledovanie mehanizmov razvitija prooksidantnyh jeffektov nanochastic metallov peremennoj valentnosti v teste Triticum Vulgare [Investigation of the development mechanisms of the prooxidant effects of variable-valence metal nanoparticles in the Triticum Vulgare test]. Mezhdunarodnyj nauchno-issledovatel'skij zhurnal. issue 8-3 (39), pp. 14-19.

8. Korotkova A.M., Lebedev S.V. and Sizova E.A., 2015. Uchastie nanochastic nikelja v reguljacii obrazovanija fenol'nyh soedinenij v kletkah Triticum Vulgare [The participation of nickel nanoparticles in the regulation of the formation of phenolic compounds in Triticum Vulgare cells]. In: All-Russian Research Institute of Beef Cattle Breeding, Innovative developments on import substitution in the agri-food sector, Proceedings of the International Conference dedicated to the 85th anniversary of the All-Russian Research Institute of Beef Cattle Breeding. Orenburg, 2015, pp. 3-5.

9. Lebedev S.V. and Gavrish I.A., 2017. Mineral'nyj sostav tkanej Eisenia Fetida v prisutstvii v srede nanochastic oksida molibdena ( $\mathrm{VI}$ ) [The mineral composition of Eisenia Fetida tissues in the presence of molybdenum (VI) oxide nanoparticles in the medium]. Mikrojelementy $v$ medicine. Vol. 18, issue 1, pp. 38-42.

10. Miroshnikov S.A. and Sizova E.A., 2017. Nanomaterialy v zhivotnovodstve (obzor) [Nanomaterials in animal husbandry (review)]. Vestnik mjasnogo skotovodstva. issue 3 (99), pp. 7-22.

11. Notova S.V., Sizova E.A., Kazakova T.V. and Marshinskaja O.V., 2016. Morfobiohimicheskie parametry krys pri vvedenii nanochastic dioksida titana [Morphobiochemical parameters of rats with the introduction of titanium dioxide nanoparticles]. Vestnik mjasnogo skotovodstva. issue 3 (95), pp. 8-14.

12. Korotkova A.M., Lebedev S.V., Kajumov F.G. and Sizova E.A., 2017. Morfofiziologicheskie izmenenija u pshenicy (Triticum VulgareL.) pod vlijaniem nanochastic metallov ( $\mathrm{Fe}, \mathrm{Cu}, \mathrm{Ni}$ ) i ih oksidov (Fe3O4, $\mathrm{CuO}, \mathrm{NiO}$ ) [Morphophysiological changes in wheat (Triticum VulgareL.) Under the influence of metal nanoparticles (Fe, $\mathrm{Cu}, \mathrm{Ni}$ ) and their oxides (Fe3O4, $\mathrm{CuO}, \mathrm{NiO})$ ]. Sel'skohozjajstvennaja biologija. Vol. 52, issue1, pp. 172-182.

13. Poljakova V.S., Sizova E.A., Miroshnikov S.A., Notova S.V. and Zavaleeva S.M., 2015. Morfofunkcional'naja harakteristika shhitovidnoj zhelezy pri vvedenii nanochastic medi [Morphological and functional characteristics of the thyroid gland with the introduction of copper nanoparticles]. Morfologija. Vol. 148, issue 6, pp. 54-58.

14. Muruev A.V., Zhapov Zh.N. and Bujantueva D.T., 2010. Nanotehnologii v razvitii zhivotnovodstva [Nanotechnology in the development of livestock]. Vestnik Burjatskoj gosudarstvennoj sel'skohozjajstvennoj akademii im. V.R. Filippova. issue 1, pp. 7-16.

15. Jausheva E.V., Miroshnikov S.A., Kosjan D.B. and Sizova E.A., 2016. Nanochasticy Fe v sochetanii s aminokislotami izmenjajut produktivnye i immunologicheskie pokazateli u cypljat-brojlerov [Fe nanoparticles in combination with amino acids alter productive and immunological parameters in broiler chickens]. Sel'skohozjajstvennaja biologija. Vol. 51, issue 6, pp. 912-920.

16. Zejnalov O.A., Kombarova S.P., Bagrov D.V., Petrosjan M.A., Tolibova G.H., Feofanov A.V. and Shajtan K.V, 2016. 0 vlijanii nanochastic serebra na fiziologiju zhivyh organizmov [The effect of silver nanoparticles on the physiology of living organisms]. Obzory po klinicheskoj farmakologii i lekarstvennoj terapii. Vol. 14, issue 4, pp. 42-51.

17. Sizova E.A., Miroshnikov S.A., Lebedev S.V., Kudasheva A.V. and Rjabov N.I., 20160 perspektivnosti nanopreparatov na osnove splavov mikrojelementov-antagonistov (na primere Fe i Co) [On the prospects of nanopreparations based on alloys of trace elements antagonists (for example, Fe and Co)]. Sel'skohozjajstvennaja biologija. Vol. 51, issue 4, pp. 553-562.

18. Orobchenko A.L., Roman'ko M.E. and Kucan A.T., 2014. Jeksperimental'no-teoreticheskoe obosnovanie primenenija nanokompozita metallov (Ag, Cu. Fe i dvuokis' Mn) dlja kur-nesushek pri uslovii hronicheskogo postuplenija s kormom (obobshhenie jeksperi-mental'nyh issledovanij) [Experimental and theoretical justification for the use of metal nanocomposite (Ag, Cu. Fe and Mn dioxide) for laying hens under the condition of chronic feed intake (generalization of experimental studies)]. Veterinarija, zootehnija $i$ biotehnologija. issue 12, pp. 32-40.

19. Nikitin A.Ju., Markova I.V., Lebedev S.V. and Sizova E.A., 2017. Ocenka fiziologo-produktivnogo potenciala cypljatbrojlerov pri chastichnoj zamene zernovoj chasti raciona i vvedenii fermentnyh preparatov v kombikorm [Evaluation of the physiological and productive potential of broiler chickens with partial replacement of the grain portion of the diet and the introduction of en- 
zyme preparations in animal feed]. Vestnik mjasnogo. issue 3 (99), pp. 171-177.

20. Pavlov A.N., 2017. Primenenie nanochastic v agropromyshlennom komplekse i pishhevoj promyshlennosti [The use of nanoparticles in the agricultural sector and the food industry]. In: St. Petersburg, Innovation science as the basis for the development of the modern state, Proceedings of the International Conference, St. Petersburg, 2017, issue. 1, pp. 254-257.

21. Rajkova A.P., 2009. Ispol'zovanie nanoporoshkov metallov dlja predposevnoj obrabotki semjan sel'skohozjajstvennyh kul'tur [The use of metal nanopowders for presowing treatment of seeds of agricultural crops]. Izvestija TSHA. issue 1, pp. 59-65.

22. Sizova E.A, 2017. Vlijanie vkljuchenija v racion nanochastic medi na uroven' kadmija v organizme cypljat-brojlerov [The effect of the inclusion of copper nanoparticles in the diet on the level of cadmium in the body of broiler chickens]. Vestnik mjasnogo. issue 1 (97), pp. 13-20.

23. Sizova E.A., 2012. Morfo-funkcional'nye kriterii optimizacii putej vvedenija nanorazmernyh chastic medi $v$ organizm zhivotnyh [Morphological and functional criteria for optimizing the introduction of nanosized copper particles into animals]. Nauchnoe obozrenie. issue 1, pp. 8-15.

24. Sizova E.A. and Miroshnikov I.S., 2014. Osobennosti obmena himicheskih jelementov v organizme zhivotnyh pri vnutrimy-shechnom vvedenii nanochastic jelementarnogo zheleza [Features of the exchange of chemical elements in animals during intramuscular administration of elemental iron nanoparticles]. Vestnik mjasnogo skotovodstva. issue 3 (86), pp. 80-84.

25. Sizova E.A., Romanova A.P. and Umrihina V.V., 2017. Ispol'zovanie fluktuirujushhej asimmetrii Alburnus Alburnus i Rana Ridibunda dlja ocenki kachestva vodnoj sredy [The use of fluctuating asymmetries of Alburnus Alburnus and Rana Ridibunda to assess the quality of the aquatic environment]. Vestnik Orenburgskogo gosudarstvennogo universiteta. issue 8 (208), pp. 76-79.

26. Sizova E.A., Tancikuzhina A.A. and Poljakova V.S., 2011. Jekspressija markera apoptoza v kletkah pecheni pri razlichnyh sposobah vvedenija nanochastic medi [Expression of apoptosis marker in liver cells with various methods of introducing copper nanoparticles]. Vestnik Orenburgskogo gosudarstvennogo universiteta. issue 12 (131), pp. 436-438.

27. Slobodskov A.A., 2014. Vlijanie vnutrimyshechnogo vvedenija nanorazmernyh chastic medi na biohimicheskie pokazateli krovi samok krys pri gestacii [The effect of intramuscular injection of nanosized copper particles on biochemical blood parameters of female rats during gestation]. Sovremennye problemy nauki i obrazovanija. issue 1, p. 328.

28. Nesterov D.V., Sipajlova O.Ju., Sizova E.A. and Shejda E.V., 2014. Sravnitel'naja ocenka vlijanija razlichnyh sposobov vvedenija nanochastic medi na obmen toksichnyh jelementov v myshechnoj tkani cypljat-brojlerov [A comparative assessment of the effect of various methods of introducing copper nanoparticles on the exchange of toxic elements in the muscle tissue of broiler chickens]. Aktual'nye problemy transportnoj mediciny. issue 3 (37), pp. 146-150.

29. Churilov G.I. and Sushilina M.M., 2008. Nanokristalicheskie metally kak jekologicheski chistye mikroudobrenija [Nanocrystalline metals as environmentally friendly microfertilizers]. „,Jekologicheskoe sostojanie prirodnoj sredy i nauchno-prakticheskie aspekty sovremennyh meliorativnyh tehnologij". Vestnyk Orenburhskoho hosudarstvennoho unyversyteta. issue 3, pp. 84-86.

30. Notova S.V., Timasheva A.B., Lebedev S.V., Sizova E.A. and Miroshnikov S.V., 2013. Jelementarnyj status i biohimicheskij sostav krovi laboratornyh zhivotnyh pri vnutrimyshechnom vvedenii asparginata i nanochastic medi [The elementary status and biochemical composition of blood of laboratory animals with intramuscular administration of aspartate and copper nanoparticles]. Vestnik Orenburgskogo gosudarstvennogo universiteta. issue 12 (161), pp. 159-163.

31. Miroshnikova E., Arinzhanov A., Kilyakova Y., Sizova E., Miroshnikov S. Antagonist metal alloy nanoparticles of iron and cobalt: impact on trace element metabolism in carp and chicken. Human and Veterinary Medicine. 2015. T. 7. № 4, C. $253-259$.

32. Pankhurst Q., Connolly J., Jones S. K. and Dobson J. Applications of magnetic nanoparticles in biomedicine. Journal of Physics D: Applied Physics. 2003. № 13, P. 87.

33. Sizova E., Yausheva E., Kosyan D., Miroshnikov S. Growth enhancement by intramuscular injection of elemental iron nano and microparticles. Modern Applied Science. 2015. T. 9. № 9, C. 17-26.

Korkh, I.V.,

Pomitun, I.A.,

Kosova, N.O.,

Boyko, N.V.,

Pankiv, L.P.,

Ryazanov, P.O.

Borodin, V.G.

Detonation synthesis ultrafine suspension of nanodiamonds influence at ewes productivity, lamb growth rate and some biochemical parameters of blood serum

The article highlights the results of $0.005 \%$ and $0.02 \%$ ultra-fine suspension of nanodiamonds introduction effective methods determination and perspectives of using as a possible activator physiological and biochemical status and improvement of the productive qualities of Kharkov interbreed type of Prekos sheep. Implementation of tasks of the work included the use of complex conventional analytical, zootechnical, biochemical, biometric methods. During the previous experiments the chemical composition of ewes' milk improvement was established, with fat content increasing and a somatic cells significant reduction. In particular, by the content fat content, ewes of the experimental group had a slight advantage of $5.7 \%$ over the representatives of the control group, whereas by the protein content, on the contrary, were inferior - by $13.3 \%$. The dry matter, dry skim and lactose mass content were almost at the same level. The suspension of nanodiamonds for the young animals provided a slight increase in the growth rate, preservations level and the improvement of the general physiological state. In general, for the period from 20 days to 3 months of age, the suspension of nanodiamonds increased the average daily growth of experimental lambs, which were 10.6-11.3 \% higher

Вісник Сумського національного аграрного університету 
than the control ones, which led to an increase of live weight during weaning at $6.7 \%$ and $6.9 \%$ against control. In addition, a slight increase of total protein by 2.7 and $8.6 \%$, albumin - by 2.2 and $3.1 \%$, gamma globulin - by 5.6 and $1.8 \%$, A / D ratio - by 9.5 and $13.5 \%$ and glucose - by $1.6 \%$ in serum of young animals of the experimental groups at the end of the experiment in both cases of comparison indicates an increase in blood-forming functions and a certain increase of metabolic processes, which is confirmed by higher body mass. However, these differences were at the trend level. Nanodiamonds suspension administration in various ways (oral and subcutaneous) had no significant difference. In order to further identify the mechanism of the effect of the suspension of nanodiamonds on the sheep organism, a longer test of its use should be conducted with the involvement of larger animal groups and the expansion of a number of physiological studies.

Key words: suspension of nanodiamonds, serum, live weight, chemical composition of milk/

Дата надходження до редакиії: 13.03.2019 р. 